\title{
Influence of Some Enzymes Addition on the Rheological Characteristics for Balady Bread Prepared By Sakha 94 Wheat Flour
}

\author{
Walid .M. Youssef ${ }^{1,2}$, Hassan H. A. Khalaf ${ }^{1}$ and Ashraf M. Sharoba ${ }^{1}$ \\ ${ }^{1}$ Food Tech. Dept., Fac. of Agric., Moshtohor, Benha Univ., Egypt. \\ ${ }^{2}$ Holding Company for Food Industry - Egyptian Baking Technology Center \\ Corresponding author: walidyoussef1@yahoo.com
}

\begin{abstract}
The grain industry occupies an important position domestically and globally as it has a major role in the daily diet of all individuals. Therefore,this study aimed to improve and change rheological properteies of wheat flour (type Sakha 94) using some enzymes as well as investigate the effect of adding these enzymes on making of balady bread with sensory evaluation of final product. The results of this study showed crude protein content was 12.98 and $11.98 \%$ for Egyptian wheat (Sakha 94) and wheat flour (72\% ext.), respectively. Also, the results showed that the whole wheat grain and wheat flour contain 27.2 and $30.4 \%$ wet gluten, respectively. Gluten index recorded 73.32 and $84.6 \%$. Also, results showed increasing dry gluten in wheat flour to be $12.6 \%$. The rheological tests is carried out using the farinograph, extensograph, mixolab and alveograph. All characteristics were improved especially with the blend coded (X1) which consists of $10 \mathrm{ppm}$ glucose oxidase and 3 ppm $\alpha$-amylase, whereas the dough giving the highest value of stability andresistance after adding this enzymes. The results of sensory evaluation of balady bread indicated that this mixture was the best addition used. Thus, It could be concluded that the addition of enzymes remained as good Organoleptic attributes for balady bread with the third day as well as fifth day compared with control sample and all treatments.
\end{abstract}

Keywords: Balady bread, Sakha 94, enzymes, Glucose oxidase (GOX) and $\alpha$-amylase.

\section{Introduction}

Wheat is an economic and important crop that provides approximately $20 \%$ of food calorie in the world. Egypt has one of the highest wheat per capita consumption levels in the world (200kg/person/year). As well as Egypt is also the world's biggest wheat importer and the General Authority for Supply Commodities (GASC) of the Ministry of Supply and Internal Trade of Egypt (MoSIT) alone is the world's biggest wheat purchaser (FAO, 2017).Common or bread wheat (Triticum aestivum) with hard or soft endosperm constitutes about $95 \%$ of total production, whereas durum wheat (Triticum durum) accounts for $5 \%$. Durum and hard wheat contain more protein (12$16 \%)$ than soft wheat $(8-10 \%)$. Wheat is the major staple crop in Egypt and viewed as a strategic commodity, which is considered a main ingredient in the Egyptian diet. Therefore, the consumers have no other choice except consuming the bread since it is still the cheapest food. Bread is the most common and traditional food around the world. Many additives such as vital gluten, emulsifiers, oxidants, and preservatives were being used to improve the quality of bread and to increase its shelf life. Use of enzymes increasingly in bread making to improve dough and bread quality leading including flexibility, mach inability, stability, loaf volume and crumb structure. On the other hand, the usage of enzymes as bread making improvers instead of chemical ones is more convenient from healthy point of view (Gerrard and Brown, 2002). The world enzyme market is in evolution and a growth of $6.8 \%$ per year is expected.
It is possible to observe that enzymes market for baked goods is expected to increase from 420 million dollars in 2010 to 900 million dollars in 2020 (Van Oort,2010). Technical enzymes are produced from three different sources include plants, animals and microorganisms. The role of microorganisms has grown considerably in recent years. The main enzyme activities found in commercial enzyme preparations are starch-degrading enzymes, proteases and pentosanases (Collaret al., 2005 and Bankaret al., 2009). The enzymes most frequently used in bread making can be divided into hydrolases, oxidoreductases, proteases, hemicellulases and lipasesuch as $\alpha$-amylases (EC 3.2.1.1),glucose oxidase $(\mathrm{GOX}) \quad(\beta$-D-glucose: oxygen 1oxidoreductase (EC 1.1.2.3.4) and xylanase....,etc. (Collaret al., 2000 and Sanz Penella et al., 2008). Most of the starch-converting enzymes belong to the $\alpha$-amylase family or family 13 glycosyl hydrolases $(\mathrm{GH})$, based on amino acid sequence and structural similarities (Svensson et al., 2002). On the other hand, the GOX catalysis the oxidation of glucose to the glucono lactone with the concomitant reduction of the oxygen to hydrogen peroxides.(Shafisoltani et al., 2014). Each enzyme can be used individually or as combination of enzymes to improve the rheological properties of the dough and the characteristics of the resulting products. Recent advances in understanding of the dough forming and overall baking processes at the molecular level have focused attention on improvements that can be achieved by application of more specially tailored enzymes alone or in combinations (Almeida and Chang, 2012). Usually, 
integrated experimental design and optimization followed by chemical analyses, rheological experiments and baking trials are necessary in order to provide answers to the more complicated questions. Therefore, this study aimed to use some enzymes to improve the qualities and characteristics of wheat flour for (type Sakha 94) as well as investigate the effect of adding these enzymes on making of Balady bread with sensory evaluation of final product.

\section{Materials and Methods}

\section{Materials:}

a. Wheat grains:

In this study Sakha 94 as a type of Egyptian wheat grains for 2016/2017 seasone, it was obtained from Wheat Research Dept, Agricultural Research Station, Sakha, Kafr-El-Sheikh city. Egypt.

\section{b. Enzymes:}

Three enzymes were used in this study as follows: glucose oxidase (GOX)(GRINDAMYL® S759) and fungal $\alpha$-amylase(GRINDAMYL® A 14000) obtained from International Company for Milling \& Bakery Supplies agent (OMEGA) for AB Enzymes Company in Germany, while baking ingredients compressed yeast, sugar and salt were obtained from local market Giza, Egypt.

\section{Methods:}

\section{Preparation of flour:}

Wheat grain was cleaned on the dockage tester (Day Co. Minneapolis, MN.), relying on air aspiration (squirrel - cage fan speed 2,215 rpm) to remove the lower density shriveled kernels and the readily separable foreign matter were discarded. Wheat grain was milled by using a Laboratory mill, Buhler model MLU-202 to (72\% extraction rate).

\section{Physical Tests:}

Hectoliter weight and thousand kernel weight were determined using stander procedures according to A.A.C.C. (2000).

\section{Chemical analysis:}

Moisture, crude protein, ether extract, crude fiber and ash content were determined according to the methods of A.O.A.C. (2006). Total carbohydrates were calculated by differences.

\section{Gluten characteristics:}

Gluten characteristics which include wet gluten, dry gluten, water-binding capacity and gluten index were estimated according to A.A.C.C. (2000).

\section{Rheological properties of wheat flour:}

\section{a. Farinograph and Extensograph test:}

Farinograph and Extensograph tests were carried out to determine the water absorption, dough development time, dough stability and dough weakening as well as elasticity, extensibility, proportion number and energy of wheat flour ( $72 \%$ extraction rate) according to the method described in A.A.C.C. (2000).

\section{b. Mixolab test:}

Dough rheological behavior was studied using Mixolab (Mixolab (Chopin, Tripetteet Renaud, Paris, France) which simultaneously determines dough characteristics during the process of mixing at constant temperature, as well as during the period of constant heating and coolingOzturk et al. (2008).Mixolab analysis was carried out at the water absorption level determined by the Consistograph following the method ofA.A.C.C. (2000).

\section{Alveograph}

Alveograph test was carried out in an Alveograph MA 82 (Chopin, Tripetteet Renaud, France) following the approved method 54-30A (A.A.C.C, 2000).

\section{d. Falling number (No.) test:}

Falling No. was determined according to the method described in A.A.C.C. (2000).

\section{Preparation of flour:}

Addition of enzymes to $1000 \mathrm{~g}$ of Sakha 94 wheat flour (72\%.Ex.) for making balady bread as follows:

\begin{tabular}{ll}
\hline Blend & Component \\
No. & \\
\hline B1 & wheat flour of Sakha 94 (control) \\
B2 & wheat flour of Sakha 94+5 ppm GOX \\
B3 & wheat flour of Sakha 94+ $10 \mathrm{ppm} \mathrm{GOX}$ \\
B4 & wheat flour of Sakha 94+ 15 ppmGOX \\
B5 & wheat flour of Sakha 94+3 ppm $\alpha$-amylase \\
B6 & wheat flour of Sakha 94+5 ppm $\alpha$-amylase \\
B7 & wheat flour of Sakha 94+ 10 ppm $\alpha$-amylase \\
X1 & wheat flour of Sakha 94+ mix(B3+B5+B9) \\
\hline
\end{tabular}

\section{Preparation of Balady bread:}

Balady bread was prepared by mixing each $1 \mathrm{~kg}$ wheat flour with the enzymes according to the levels of enzymes mentioned above from blend $\mathrm{B} 2$ to $\mathrm{X} 1$, as well as with ingredients including $1.5 \%$ compressed yeast, $1.5 \%$ sodium chloride and water as needed by farinograms. The mixture was well mixed in mixer (250 rpm) for $20 \mathrm{~min}$. The dough was left for fermentation at $30^{\circ} \mathrm{C}$ for $15 \mathrm{~min}$. After fermentation, the dough was divided into $125 \mathrm{~g}$ pieces. Each piece was molded on a wooden board previously covered with fine layer of bran and left to ferment about 15 min at the same mentioned temperature and relative humidity. The fermented dough pieces were baked at $380-400^{\circ} \mathrm{C}$ for $1-2 \mathrm{~min}$ in electric oven. The loaves were allowed to cool at room temperature before organoleptic evaluation (Yaseen, 1985).

7.1. Sensory evaluation of balady bread:

Bread loaves were allowed to cool for about $1 \mathrm{~h}$ before evaluation. Balady bread loaves were organoleptically evaluated for color (20), appearance (20), taste (20), flavor (20), separation of layers (20) and overall acceptability (100) according to ElFarraet al. (1982). 


\section{Statistical analysis:}

The statistical analysis was carried out using oneway ANOVA using SPSS, ver. 22 (IBM Corp. Released 2013). Data were treated as a complete randomization design according to Steel $\boldsymbol{e t}$ al. (1997). Multiple comparisons were carried out applying Duncun test the significance level was set at $<0.05$.

\section{Results and Discussion}

\section{Chemical composition and physical characterization}

The chemical compositions of whole wheat grain and wheat flour are shownin Table (1). The results indicated that the moisture range from 12.6 to $13.6 \%$, crude protein content was 12.98 and $11.98 \%$ with whole wheat grain and wheat flour (72\% ext.), respectively. On the other hand total carbohydrate was increased to be $72.48 \%$ with wheat flour.Egyptian wheat grain (Sakha 94) had the highest value of falling number $437 \mathrm{Sec}$, while wheat flour the falling number was 380.These results are in agreement with between those obtained by El-Porai et al. (2013), they found that falling number ranged 379 to $495 \mathrm{sec}$, as well as gluten index was 84.7 to $87.9 \&$ a. Crude protein, crude fiber and ash in whole wheat grain were $12.98 \%$, $2.23 \%$ and 1.6 , respectively. This result is converging with Mehasen et al. (2014). Physical characterization for whole wheat grain through thousand kernel weight is one of the most important parameter are used to indicate the grain characters and factors affected of the wheat grain parameters such as genotype and environment, etc. That thousand kernel weight is 47.8g. Hectoliter affected by many factors such as genotype, environment and fertilizer, so Hectoliter recorded $83.1(\mathrm{~kg} /$ hectoliter) these results coincided with (El-Kalla et al., 2010 and Nemat et al., 2013 and Ali, 2017). Many studies are shown to presence the relation between the thousand kernel weight and protein content and then quality of wheat products, which depend mainly on genetic factor and environmental condition (Ramya et al., 2010). As well as the wet gluten, gluten index and dry gluten are shown in Table (1). The results showed that the whole wheat grain (Sakha 94) and wheat flour contain 27.2 and $30.4 \%$ wet gluten, respectively. Gluten index recorded 73.32 and $84.6 \%$. Also, results showed the increasing of dry gluten in wheat flour to be $12.6 \%$.

Table 1. Chemical composition and physical parameters of whole wheat grain and wheat flour for Sakha 94.

\begin{tabular}{lcc}
\hline Characteristic & Whole wheat grain & Wheat flour (72\% ext.) \\
\hline Moisture content (\%) & 12.6 & 13.6 \\
Ash content (db.) (\%) & 1.60 & 0.54 \\
Crude protein (N×5.7) (\%) & 12.98 & 11.98 \\
Ether extract (\%) & 1.41 & 0.93 \\
Crude fiber (\%) & 2.23 & 0.47 \\
Total carbohydrates* & 69.18 & 72.48 \\
Falling Number (Sec.) & 437 & 380 \\
Wet gluten (\%) & 27.2 & 30.4 \\
Gluten index (\%) & 73.32 & 84.6 \\
Dry gluten (\%) & 9.2 & 12.6 \\
Hectoliter (kg/hectoliter) & 83.1 & \\
Thousand kernel weight (g) & 47.8 & \\
* (calculated by difference) & &
\end{tabular}

2. Effect of adding some enzymes to flour wheat (Sakha 94) on rheological properties

\subsection{Farinograph properties:}

Data in Table (2) show the effect of addition enzymes at different levels to wheat flour (Sakha 94) on Farinograph characteristics. Water absorption increased with adding enzymes, so it was $64.2 \%$ in blend coded by (X1) which consists of 10 ppm GOX and 3 ppm $\alpha$-amylase, while it was $58.2 \%$ in control sample. Dough stability was $5 \mathrm{~min}$ in control sample and blend B5, while increased dough stability to be 9 min in blend coded (X1). The increased stability time indicated the robustness of the flour and convenience of making balady bread. Mixing tolerance decreased in blend coded (X1) to 20 B.U compared with control 60 B.U as (Fig 1) shows. On the other hand, it increased to 80 B.U. after addition of $\alpha$-amylase as with blend coded B6 and B7 which contains 50 and $10 \mathrm{ppm} \alpha$-amylase, respectively.

Disulfide bonds play a major role in determining dough properties. Exposure to oxidants can increases dough strength by the oxidation of sulfhydryl groups to disulfide bonds; So GOX promotes the oxidation of sulfhydryl groups and the subsequent formation of disulfide bonds between cysteine moieties and so increase in unextractable polymeric proteins in wheat flour, which was attributed to an increase in disulfide bonding between protein subunits (Steffolani et al., 2010 and Whitney et al., 2014)

On the other hand, $\alpha$-amylases limite amylopectin re-crystallization and hence amylopectin network formation and consequent water immobilization, ultimately resulting in a softer, more water-plasticized crumb with greater resilience (Bae et al., 2014) 
Table 2. Farinograph properties for dough after adding GOX and $\alpha$-aAmyleas and Xylanase to Sakha 94 wheat flour (72\% ext):

\begin{tabular}{lccccc}
\hline Blend No. & $\begin{array}{c}\text { Water } \\
\text { absorption }\end{array}$ & $\begin{array}{c}\text { Mixing time } \\
(\mathbf{m i n})\end{array}$ & $\begin{array}{c}\text { Stability time } \\
(\mathbf{m i n})\end{array}$ & $\begin{array}{c}\text { Mixing } \\
\text { tolerance } \\
\text { index (B.U) }\end{array}$ & $\begin{array}{c}\text { Weakning of } \\
\text { dough (B.U) }\end{array}$ \\
\hline B1(Control) & 58.2 & 2.5 & 5.0 & 60 & 80 \\
B2 & 58.4 & 3.0 & 5.5 & 40 & 60 \\
B3 & 58.9 & 4.0 & 8.0 & 30 & 20 \\
B4 & 59.5 & 3.5 & 8.4 & 30 & 20 \\
B5 & 58.2 & 3.0 & 5.0 & 60 & 90 \\
B6 & 58.3 & 2.5 & 4.0 & 80 & 100 \\
B7 & 58.4 & 2.5 & 4.0 & 80 & 110 \\
X1 & 64.2 & 3.5 & 9.0 & 20 & 20 \\
\hline
\end{tabular}

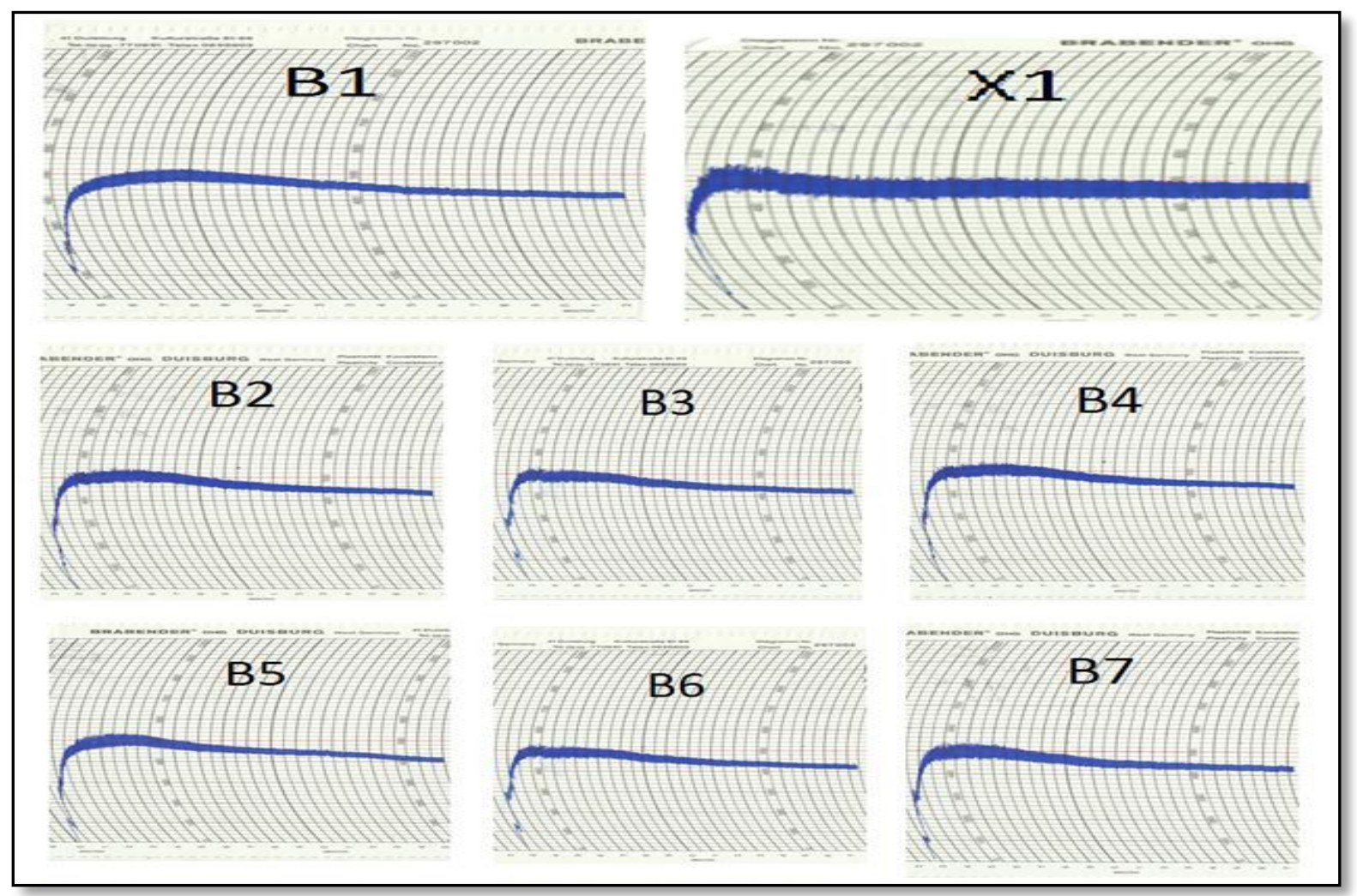

Fig. (1): Farinograph diagrams for wheat flour (Sakha 94) after adding enzymes.

\subsection{Extensograph parameters:}

Results presented in Table (3) and illustrated in Fig. (2) showed extensograph parameters for wheat flour (Sakha 94) after adding some enzymes to improve production of balady bread. Data indicate that resistance with control sample was 420 B.U. the mixtures containing GOX recorded highest resistance as B3 and B4 620 and 625 B.U. The highest value was 670 B.U with (X1). The extensibility (E) showed a value of $130 \mathrm{~mm}$ for control (Sakha 94 wheat flour $72 \%)$. Increases that value together add enzymes to $160 \mathrm{~mm}$ with blend coded (X1). The relative number was dependent on the results of (R) and (E). Therefore, a similar relationship was found of the relative number ( $\mathrm{R} / \mathrm{E}$ ) of the dough. These results coincided with Shafisoltani et al. (2014) and EL Rashidy, (2015). 
Table 3. Extensograph properties for dough after adding GOX and $\alpha$-amyleas and Xylanase to Sakha 94 wheat flour (72\% ext):

\begin{tabular}{ccccc}
\hline Blend No. & $\begin{array}{c}\text { Resistant to } \\
\text { extension }(\mathbf{R})(\mathbf{B . U})\end{array}$ & $\begin{array}{c}\text { Extensibility (E) } \\
(\mathbf{~ m m})\end{array}$ & $\begin{array}{c}\text { Proportional number } \\
(\mathbf{R}) \mathbf{E})\end{array}$ & Energy $\left(\mathbf{c m}^{2}\right)$ \\
\hline B1 (Control) & 420 & 130 & 3.23 & 108 \\
B2 & 480 & 140 & 3.42 & 123 \\
B3 & 620 & 150 & 4.13 & 155 \\
B4 & 625 & 145 & 4.31 & 156 \\
B5 & 420 & 135 & 3.11 & 109 \\
B6 & 410 & 150 & 2.73 & 100 \\
B7 & 430 & 135 & 3.18 & 112 \\
X1 & 670 & 160 & 4.18 & 165 \\
\hline
\end{tabular}

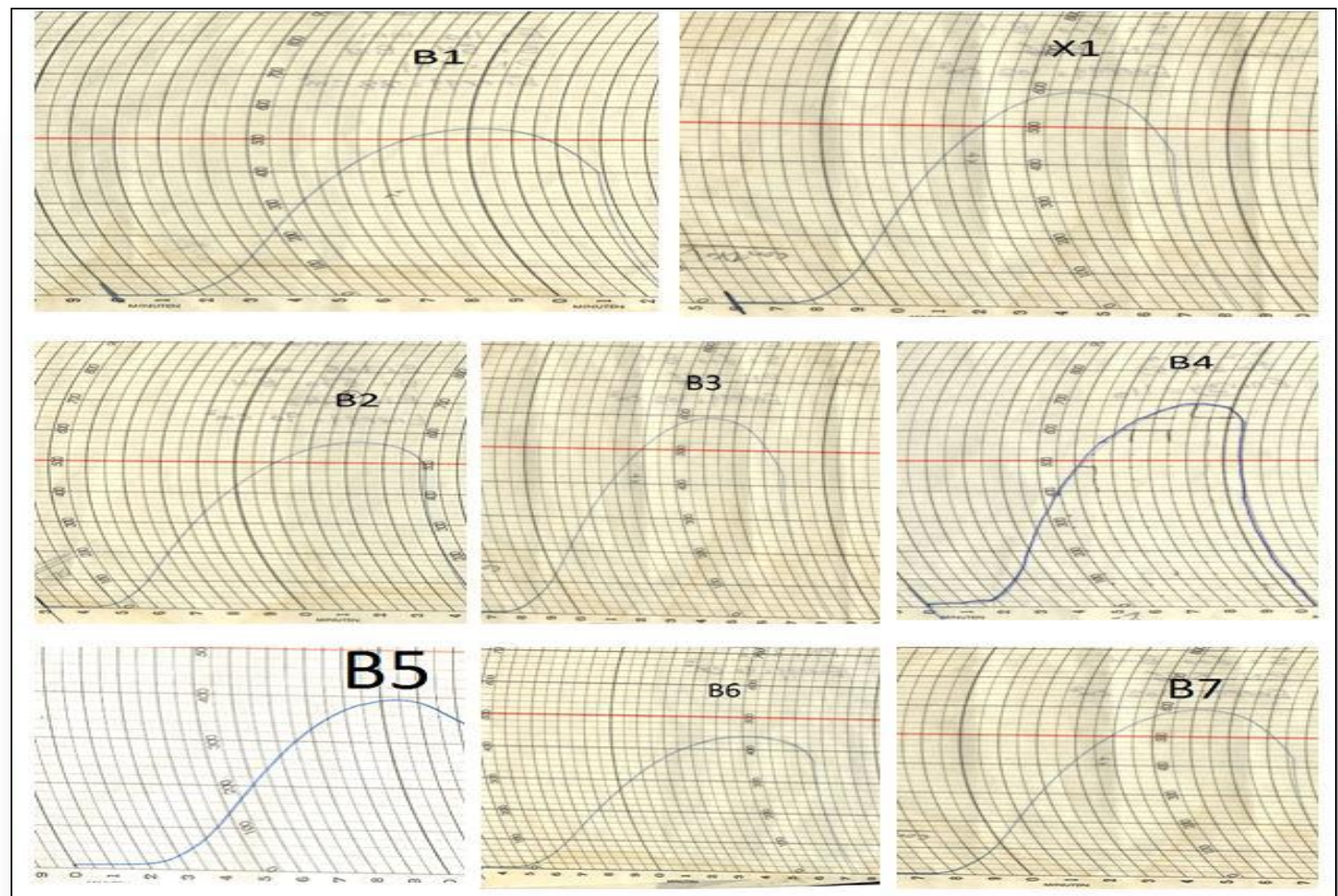

Fig. (2): Extensograph diagrams for wheat flour (sakha 94) after adding enzymes.

\subsection{Mixolab parameters of Sakha 94 wheat flour} after addition some enzymes:

The results Table (4) and Fig. (3) showed the effect of enzymes addition at different levels on Mixolab properties. The results indicated increasing stability with the adding of enzymes compared with control sample (from $9.63 \mathrm{~min}$ to $12.13 \mathrm{~min}$ in sample coded
(X1) which mixture by $10 \mathrm{ppm}$ GOX and $3 \mathrm{ppm} \alpha-$ amylase. The effect of enzymes was found on the values of dough development with first stage (C1) from $1.28 \mathrm{Nm}$ in control sample to $9.5 \mathrm{Nm}$ in sample (X1), but did not effect in the stage five (C5)in all samples compared with control. Gluten, viscosity and amylase were enhance with all treatment by enzymes.

Table 4. Mixolab characteristics of Sakha 94 wheat flour after addition some enzymes:

\begin{tabular}{|c|c|c|c|c|c|c|c|c|c|c|c|c|}
\hline $\begin{array}{c}\text { Blend } \\
\text { No. }\end{array}$ & $\begin{array}{c}\begin{array}{c}\text { Stability } \\
(\mathrm{min})\end{array} \\
\end{array}$ & Absorption & Mixing & Gluten+ & Viscosity & Amylase & $\begin{array}{c}\text { Retro } \\
\text { gradation }\end{array}$ & $\begin{array}{c}\text { C1 } \\
\text { (Nm) }\end{array}$ & $\begin{array}{c}\mathrm{C2} \\
(\mathrm{Nm})\end{array}$ & $\begin{array}{c}\text { C3 } \\
(\mathrm{Nm})\end{array}$ & $\begin{array}{c}\mathbf{C 4} \\
(\mathrm{Nm})\end{array}$ & $\begin{array}{c}\mathbf{C 5} \\
(\mathrm{Nm})\end{array}$ \\
\hline B1 & 9.63 & 4 & 2 & 6 & 5 & 7 & 7 & 1.28 & 16.37 & 25.07 & 28.60 & 45.02 \\
\hline B2 & 10.63 & 5 & 2 & 6 & 5 & 8 & 7 & 1.36 & 16.00 & 23.03 & 28.87 & 45.00 \\
\hline B3 & 10.62 & 6 & 3 & 7 & 6 & 8 & 6 & 1.73 & 15.60 & 22.05 & 26.23 & 45.00 \\
\hline B4 & 10.53 & 6 & 4 & 8 & 8 & 8 & 8 & 1.35 & 15.92 & 44.85 & 44.90 & 45.02 \\
\hline B5 & 9.60 & 6 & 2 & 8 & 7 & 8 & 8 & 1.43 & 15.85 & 23.02 & 28.83 & 45.00 \\
\hline B6 & 9.72 & 5 & 4 & 4 & 8 & 8 & 8 & 1.15 & 16.10 & 28.13 & 29.78 & 45.00 \\
\hline B7 & 9.57 & 5 & 4 & 6 & 7 & 8 & 8 & 1.28 & 16.57 & 27.72 & 30.38 & 45.02 \\
\hline X1 & 12.13 & 7 & 8 & 8 & 7 & 8 & 8 & 9.50 & 17.57 & 25.20 & 30.22 & 45.00 \\
\hline
\end{tabular}




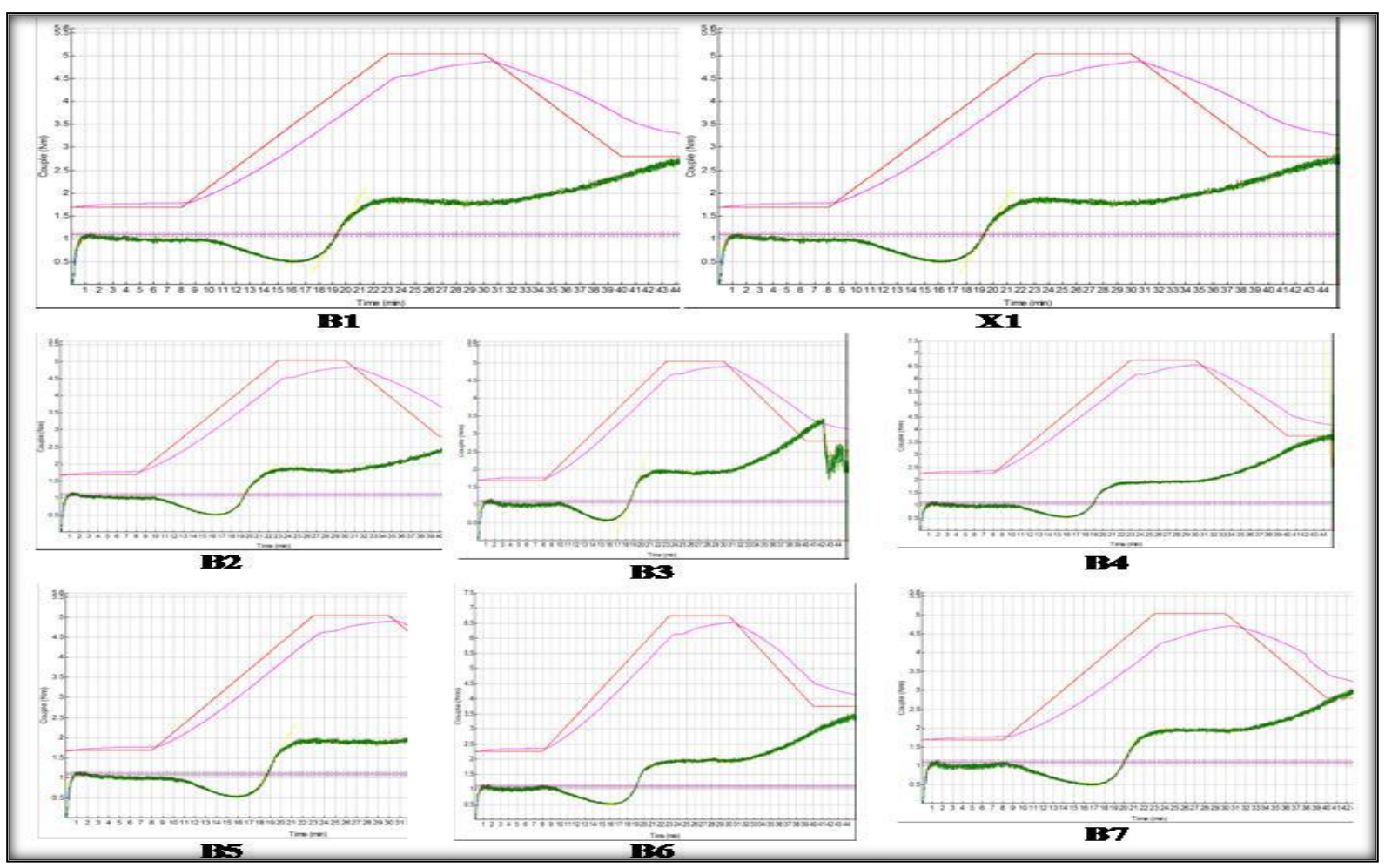

Fig. 3 Mixolab diagrams of Sakha 94 wheat flour after addition some enzymes

2. 4. Alveograph characteristicsof Sakha 94 wheat flour after addition some enzymes:

The results in Table (5) showed that, the value of resistance $(\mathrm{P})$ was $95 \mathrm{~mm}$ in control sample increased to 108 with the wheat flour after adding some enzymes as blend No. (X1). GOX increased covalent crosslinking among proteins markedly into the gluten network Compared to the control sample (Caballero et al., 2007 and Sahnoun et al., 2016). On the other hand elasticity (L) was decreased in all samples compared with control sample was $100 \mathrm{~mm}$. The resistance to elasticity $(\mathrm{P} / \mathrm{L})$ also increased with the use of enzymes, compared to the control sample as
(Fig 4). Gluten cross-linking enzymes play an important role in the present baking processes. Through different biochemical mechanisms (the oxidative coupling of thiol groups, the crosslink of tyrosine residues due to the action of intermediate reactive compounds such as hydrogen peroxide, the acyl-transfer reaction between amino acid residues), these enzymes promote the formation of covalent bonds between polypeptide chains within a protein or between different proteins, improving functional behaviour of dough during bread-making process (Caballeroet al., 2007).

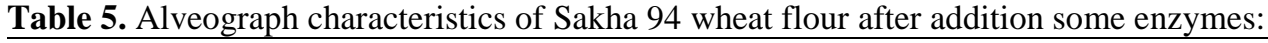

\begin{tabular}{cccc}
\hline Blend (No.) & P $(\mathbf{m m})$ & L $(\mathbf{m m})$ & W(P/L Ratio) \\
\hline B1 (control) & 95 & 100 & 0.95 \\
B2 & 89 & 93 & 0.96 \\
B3 & 98 & 82 & 1.20 \\
B4 & 92 & 72 & 1.28 \\
B5 & 96 & 86 & 1.12 \\
B6 & 94 & 85 & 1.11 \\
B7 & 93 & 102 & 0.91 \\
X1 & 108 & 77 & 1.40 \\
\hline
\end{tabular}




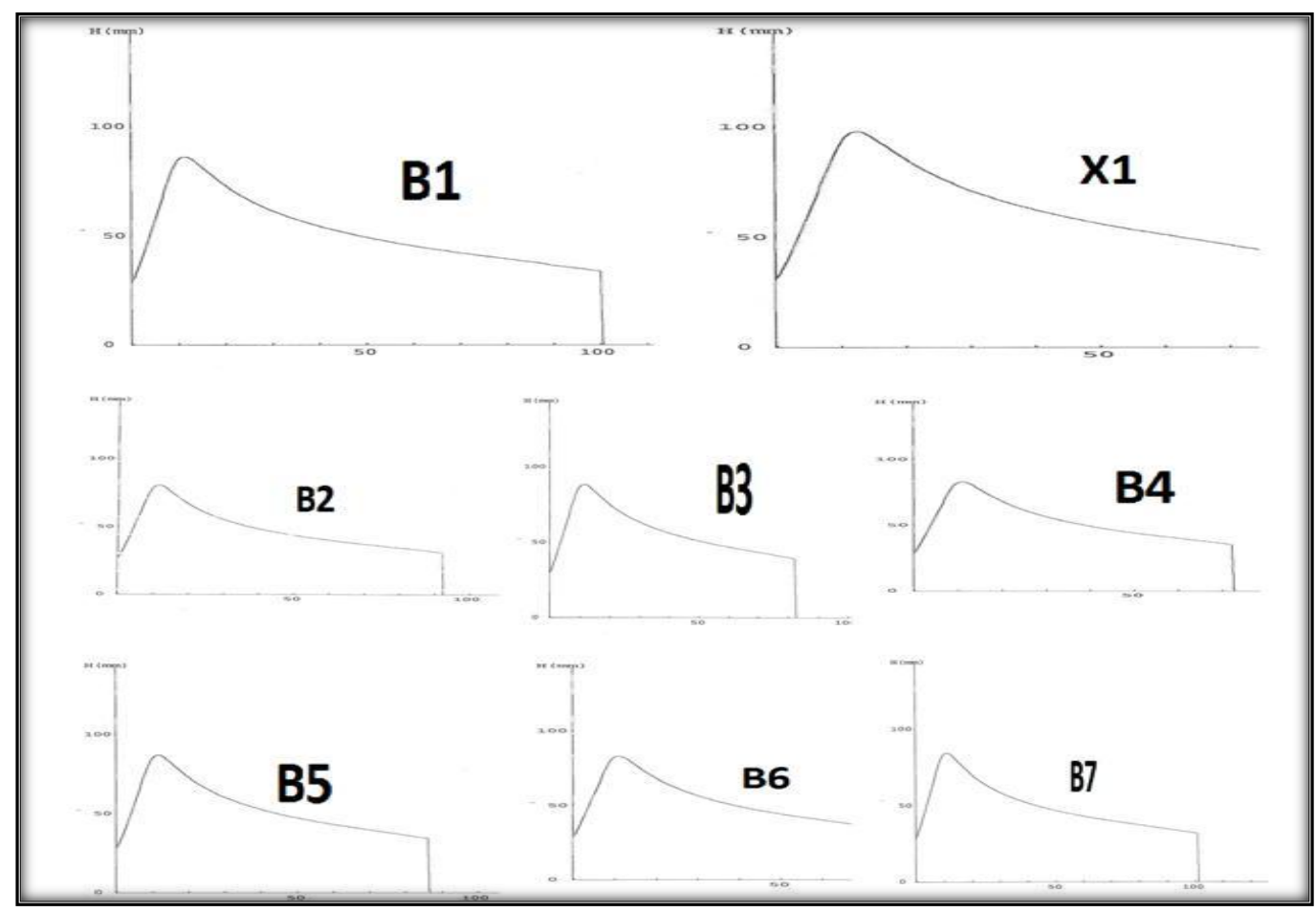

Fig. (4): Alveograph diagrams of Sakha 94 wheat flour after addition some enzymes

\subsection{Sensory evaluation of balady bread:}

Data in Table (6) indicated that there are significant differences $(\mathrm{p} \leq 0.05)$ between all enzymes. The results showed that there are a significant difference $(\mathrm{P}>0.05)$ between any blend, as well as between storage period. Storage for the fifth day showed significant deterioration in sensory evaluation

The obtained data indicated that treatments coded (X1) giving marked $(\mathrm{p} \leq 0.05)$ improvement in all attributes compared with control samples. Also, these results dramatically agreed with rheological parameters must be referred to the Blend (X1) which consist of $10 \mathrm{ppm}$ GOX and $3 \mathrm{ppm} \alpha$-amylase gave the best results in all organoleptic attributes. On the other hand, results showed that the blend (X1) remained as good arganoleptic attributes the third day as well as the fifth day compared with control sample and all treatments. During bread storage, the gelatinised starch (amylopectin) network, present in soft, fresh bread, is gradually transformed into an extensive, partially crystalline, permanent amylopectin network, with amylopectin crystallites acting as junction zones. This network increasingly accounts for the bulk rheological behaviour of aging bread crumb. The efficiency of anti-staling amylases can be related to the extent they limit the formation and the strength of the permanent amylopectin network, and the water immobilisation. Conventional alpha-amylases weaken the amylopectin network by cutting the long polymer chains connecting the crystalline regions, but have little effect on amylopectin recrystallisation. In contrast, maltogenic alpha-amylase primarily shortens the amylopectin side chains, thus hindering amylopectin recrystallisation, and the concomitant network formation and water immobilisation(Hug-Iten et al., 2003 and Goesaert et al., 2009).

\subsection{Effect of addition some enzymes on alkaline} water retention capacity (AWRC) of balady bread:

Effects of addition different concentrations from GOX and $\alpha$-amylase to wheat flour (Sakha 94) on alkaline water retention capacity (AWRC \%) during storage of balady bread for 1,3 and 5 days at $25^{\circ} \mathrm{C}$ are shown in Table (7). It could be noticed that rate decrease (RD\%) of control balady bread increased with increasing storage period. While, addition of enzymes the RD\% decrease, so that the freshness increased to these levels and improved the staling rate comparing with control sample. Where the RD \% in control sample was 10.9 to $57.01 \%$ after storage for 1 to 5 days, respectively. The RD\% was 0.6 to $29.43 \%$ and 1.5 to $31.8 \%$ with blends coded $\mathrm{B} 9$ and X1, respectively; While in the same storage periods after addition enzymes. This improvement may be due to increased break down starch to glucose units with production of higher levels of reducing sugars, a factor that would raise the water absorption and increase bread shelf-life (Azzeh and Amr, 2009 and Yaseen et al., 2010). 
Table 6. Sensory evaluation of Balady bread treated by different doses of enzymes:

\begin{tabular}{|c|c|c|c|c|c|c|c|c|c|c|c|}
\hline \multirow{2}{*}{ 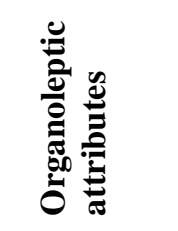 } & \multicolumn{8}{|c|}{ Blends No. } & \multicolumn{3}{|c|}{ Storage periods } \\
\hline & B1 & B2 & B3 & B4 & B5 & B6 & B7 & $\mathbf{X} 1$ & zero day & $\begin{array}{l}\text { Third } \\
\text { day }\end{array}$ & $\begin{array}{l}\text { Fifth } \\
\text { day }\end{array}$ \\
\hline Color & $\begin{array}{l}9.5 \pm \\
7.3^{\mathrm{f}}\end{array}$ & $\begin{array}{c}12.3 \pm \\
2.7^{\mathrm{d}}\end{array}$ & $\begin{array}{l}14.1 \pm \\
3.04^{\mathrm{c}}\end{array}$ & $\begin{array}{c}11.7 \pm \\
2.7^{\mathrm{e}}\end{array}$ & $\begin{array}{c}15.0 \pm \\
2.3^{\mathrm{b}}\end{array}$ & $\begin{array}{l}8.1 \pm \\
6.2^{\mathrm{h}}\end{array}$ & $\begin{array}{l}8.7 \pm \\
6.5^{g}\end{array}$ & $\begin{array}{c}16.3 \pm \\
2.0^{\mathrm{a}}\end{array}$ & $16.6 \pm 1.7^{\mathrm{A}}$ & $11.7 \pm 2.06^{\mathrm{B}}$ & $8.2 \pm 5.9^{\mathrm{C}}$ \\
\hline Appearance & $\begin{array}{l}9.5 \pm \\
7.4^{\mathrm{d}}\end{array}$ & $\begin{array}{l}11.3 \pm \\
4.5^{\mathrm{c}}\end{array}$ & $\begin{array}{l}13.8^{ \pm} \\
3.2^{\mathrm{b}}\end{array}$ & $\begin{array}{c}18.8 \pm \\
4.3^{\mathrm{c}}\end{array}$ & $\begin{array}{l}15.0 \pm \\
2.5^{\mathrm{a}}\end{array}$ & $\begin{array}{l}7.8 \pm \\
5.6^{\mathrm{e}}\end{array}$ & $\begin{array}{l}8.5 \pm \\
7.5^{\mathrm{e}}\end{array}$ & $\begin{array}{l}15.5 \pm \\
2.5^{\mathrm{a}}\end{array}$ & $16.6 \pm 2.04^{\mathrm{A}}$ & $11.8 \pm 2.2^{\mathrm{B}}$ & $6.5 \pm 5.5^{\mathrm{C}}$ \\
\hline Taste & $\begin{array}{l}9.1 \pm \\
7.2^{\mathrm{de}}\end{array}$ & $\begin{array}{l}8.9 \pm \\
6.9^{\mathrm{de}}\end{array}$ & $\begin{array}{l}11.2 \pm \\
6.5^{\mathrm{c}}\end{array}$ & $\begin{array}{l}9.6 \pm \\
5.9^{\mathrm{d}}\end{array}$ & $\begin{array}{l}12.3 \pm \\
5.5^{\mathrm{b}}\end{array}$ & $\begin{array}{l}7.5 \pm \\
5.9^{f}\end{array}$ & $\begin{array}{l}8.5 \pm \\
6.6^{\text {ed }}\end{array}$ & $\begin{array}{c}13.9 \pm \\
4.6^{\mathrm{a}}\end{array}$ & $16.7 \pm 1.7^{\mathrm{A}}$ & $11.6 \pm 2.5^{\text {В }}$ & $2.1 \pm 2.7^{\mathrm{C}}$ \\
\hline Flavor & $\begin{array}{l}9.3 \pm \\
7.5^{c}\end{array}$ & $\begin{array}{l}9.1 \pm \\
7.1^{\text {cd }}\end{array}$ & $\begin{array}{l}12.1 \pm \\
5.4^{\mathrm{b}}\end{array}$ & $\begin{array}{l}9.8 \pm \\
4.8^{\mathrm{c}}\end{array}$ & $\begin{array}{l}11.4 \pm \\
6.3^{\mathrm{b}}\end{array}$ & $\begin{array}{l}7.5 \pm \\
5.8^{\mathrm{e}}\end{array}$ & $\begin{array}{l}8.4 \pm \\
6.3^{\mathrm{d}}\end{array}$ & $\begin{array}{c}13.6 \pm \\
5.2^{\mathrm{a}}\end{array}$ & $16.6 \pm 2.3^{\mathrm{A}}$ & $11.5 \pm 2.4^{\mathrm{B}}$ & $2.3 \pm 2.6^{\mathrm{C}}$ \\
\hline $\begin{array}{l}\text { Separation } \\
\text { lavers }\end{array}$ & $\begin{array}{l}8.5 \pm \\
6.6^{\mathrm{d}}\end{array}$ & $\begin{array}{l}12.1 \pm \\
2.3^{\mathrm{c}}\end{array}$ & $\begin{array}{l}14.2 \pm \\
2.2^{\mathrm{b}}\end{array}$ & $\begin{array}{l}12.03 \pm \\
3.4^{\mathrm{c}}\end{array}$ & $\begin{array}{l}13.5 \pm \\
3.9^{\mathrm{b}}\end{array}$ & $\begin{array}{l}8.0 \pm \\
6.2^{\mathrm{d}}\end{array}$ & $\begin{array}{l}8.2 \pm \\
6.2^{\mathrm{d}}\end{array}$ & $\begin{array}{l}16.4 \pm \\
2.3^{\mathrm{a}}\end{array}$ & $16.3 \pm 2.2^{\mathrm{A}}$ & $11.5 \pm 2.5^{\mathrm{B}}$ & $7.1 \pm 5.7^{\mathrm{C}}$ \\
\hline $\begin{array}{l}\text { Overall } \\
\text { acceptability }\end{array}$ & $\begin{array}{l}45.9^{ \pm} \\
36.3^{\mathrm{d}}\end{array}$ & $\begin{array}{l}54.2 \pm \\
22.2^{\mathrm{c}}\end{array}$ & $\begin{array}{l}64.9 \pm \\
19.9^{\mathrm{b}}\end{array}$ & $\begin{array}{l}55.4 \pm \\
20.1^{\mathrm{c}}\end{array}$ & $\begin{array}{l}67.2 \pm \\
18.9^{b}\end{array}$ & $\begin{array}{l}39.1 \pm \\
30.1^{\mathrm{f}}\end{array}$ & $\begin{array}{l}42.2 \pm \\
32.1^{\mathrm{e}}\end{array}$ & $\begin{array}{l}75.0 \pm \\
15.4^{\mathrm{a}}\end{array}$ & $82.8 \pm 8.4^{\mathrm{A}}$ & $58.0 \pm 10.7^{\mathrm{B}}$ & $25.0 \pm 21.4^{\mathrm{C}}$ \\
\hline
\end{tabular}

Mean values in the same row (as a small letter) \& (as a capital letter) with the same letter are not significant different at 0.05 level.

Table 7. Effect of addition some enzymes on alkaline water retention capacity (AWRC \%) for Balady bread made from Sakha 94 wheat flour (72\% ext) during storage at $25 \pm 2{ }^{\circ} \mathrm{C}$.

\begin{tabular}{|c|c|c|c|c|c|c|c|c|}
\hline \multirow[t]{3}{*}{ Blend No. } & \multirow{3}{*}{$\begin{array}{l}\text { Zero } \\
\text { time }\end{array}$} & \multicolumn{6}{|c|}{ Storage period (Day) } & \multirow{3}{*}{$\begin{array}{c}\text { Average for } \\
\text { blend }\end{array}$} \\
\hline & & \multicolumn{2}{|c|}{1} & \multicolumn{2}{|c|}{3} & \multicolumn{2}{|c|}{5} & \\
\hline & & AWRC & RD \% & AWRC & RD \% & AWRC & RD \% & \\
\hline B1(control) & 281.2 & 250.3 & 10.9 & 201.1 & 28.5 & 120.9 & 57.01 & $213.37 \pm 34.9^{b}$ \\
\hline B2 & 280.1 & 258.4 & 7.7 & 200.2 & 28.5 & 122.1 & 56.41 & $215.20 \pm 35.3^{\mathrm{b}}$ \\
\hline B3 & 280.4 & 271.3 & 3.4 & 210.3 & 25.0 & 135.5 & 51.67 & $224.37 \pm 33.5^{b}$ \\
\hline B4 & 278.8 & 257.4 & 7.6 & 203.4 & 27.1 & 134.5 & 51.75 & $218.52 \pm 32.2^{\mathrm{b}}$ \\
\hline B5 & 282.5 & 264.1 & 6.5 & 224.3 & 20.6 & 127.4 & 54.91 & $224.57 \pm 34.6^{b}$ \\
\hline B6 & 280.5 & 257.8 & 8.1 & 211.4 & 24.6 & 125.2 & 55.36 & $218.72 \pm 34.3^{b}$ \\
\hline B7 & 280.2 & 255.5 & 8.8 & 215.1 & 23.2 & 124.6 & 55.53 & $218.85 \pm 34.1^{\mathrm{b}}$ \\
\hline $\mathbf{X} 1$ & 285.5 & 281.2 & 1.5 & 239.4 & 16.1 & 194.5 & 31.87 & $250.15 \pm 21.3^{a}$ \\
\hline $\begin{array}{c}\text { Average } \\
\text { for periods }\end{array}$ & $281.1 \pm 0.84^{\mathrm{a}}$ & \multicolumn{2}{|c|}{$261.9 \pm 3.17^{b}$} & \multicolumn{2}{|c|}{$213.1 \pm 4.28^{c}$} & \multicolumn{2}{|c|}{$135.6 \pm 9.5^{\mathrm{d}}$} & \\
\hline
\end{tabular}

\section{References}

A.A.C.C. (2000). American Association of Cereal Chemists. Approved method of the A.A.C.C. $10^{\text {th }}$ ed. Association of Cereal Chemists, st., paul, Minnesota, USA.

A.O.A.C. (2006). Official Methods of Analysis. $18^{\text {th }}$ Edition, Association of Official Analytical Chemists, Gaithersburgs, MD., USA.

Ali, M. M. A. (2017).Stability Analysis of Bread Wheat Genotypes under Different Nitrogen Fertilizer Levels. J. Plant Production, Mansoura Univ.. 8 (2): $261-275$.

Almeida, E. L and Chang, Y. K. (2012). Effect of the addition of enzymes on the quality of frozen pre-baked French bread substituted with whole wheat flour. LWT - Food Science and Technology, 49(1): 64-72.

Azzeh, F.S.and Amr, A.S. ( 2009 ). Effect of gamma irradiation on physical characteristics of Jordanian durum wheat and quality of semolina and lasagna products. Radiation Physics and Chemistry 78 818-822.
Bae, W.; Lee, S.H.; Yoo, S.H. and Lee, S. (2014). Utilization of a maltotetraose-producing amylase as a whole wheat bread improver: dough rheology and baking performance. Journal of Food Science, 79(8): E1535-1540.

Bankar, S.B.; Bule, M. V.; Singhal, R. S and Ananthanarayan L. (2009). Glucose oxidase An overview. Biotechnology Advances, 27(4): 489-501.

Caballero, P. A., Gomez, M., and Rosell, C. M. (2007). Improvement of dough rheology, bread quality and bread shelf-life by enzymes combination. Journal of food engineering, 81(1): 42-53.

Collar C.; Martinez, J. C.; Andreu, P and Armero E. (2000). Effects of enzymes associations on bread dough performance. A response surface analysis. Food Science and Technology International,6(3): 217-226.

Collar, C.; Bollaín, C and Angioloni, A. (2005) Significance of microbial transglutaminase on the sensory, mechanical and crumb grain pattern of 
enzyme supplemented fresh pan breads. Journal of Food Engineering, 70(4): 479-488.

EL Rashidy, L. A. F. (2015). Using of some enzymes to improve the quality of some bakery products. Food Science Department Faculty of Agriculture., Benha University.

El-Farra, A.A., Khorshid, A.M., Mansour, S.M. and Elias, A.N. (1982) Studies on the possibility of supplementation of balady bread with various commercial soy-products. Materials of 1 st Egyptian Conferance on Bread Research, Cairo, pp. 9-23.

El-Kalla, S. E.; Leillah, A. A.; El-Emery , M. I. and Kishk, A. M.S. (2010). Performance of some wheat (triticumaestivum 1.) cultivars under late sowing in newly reclaimed soils. J. Plant Production, Mansoura Univ.,1 (5): 689 - 697.

El-Porai, E.S.; Salama,A. E.; Sharaf, A. M.; Hegazy, A.I and Gadallah, M.G. E. (2013). Effect of different milling processes on Egyptian wheat flour properties and pan bread quality. Annals of Agricultural Science, 58(1): 51-59.

FAO, Food and Agriculture Organization. (2017). Satistical databases. Food Composition Table for Use in the Near East. Food and Agriculture Organization.

Gerrard, J.A. and. Brown, P. K. (2002). Protein crosslinking in food: methods, consequences, applications. Trends Food Science Technology, 13: 389-397.

Goesaert , H.; Slade, L.; Levine ,H and . Delcour, J. A. (2009). Amylases and bread firming - an integrated view. Journal of Cereal Science, 50:345-352

Hug-Iten, S., Escher, F., Conde-Petit, B. (2003). Staling of bread: role of amylose and amylopectin and influence of starch-degrading enzymes. Cereal Chemistry 80, 654-661

Mehasen, S. A. S.; El-Gizawy, N. Kh.;. Sharoba, A. M.; Soliman, S. A and Khalil, T. R. M. (2014). Yield and chemical composition of bread wheat cultivars as affected by some skipping irrigation.Minufiya J. Agric. Res.Vol.39 No. 3.

Nemat A.; Noureldin .; Saudy,H. S.; Ashmawy, F.; Saed, H. M. (2013). Grain yield response index of bread wheat cultivars as influenced by nitrogen levels. Annals of Agricultural Science, 58(2): 147152.

Ozturk, S.; Kahraman, K., Tiftik, B. and Koksel, H. (2008). Predicting the cookie quality of flours by using Mixolab®. European Food Research and Technology, 227(5), 1549-1554.

Ramya, P.; Chaubal, A.; Kulkarni, K.; Gupta, L.; Kadoo, N.; Dhaliwal, H.S.; Chhuneja, P.; Lagu,
M. and Gupt, V. (2010). QTL mapping of 1000kernel weight, kernel length, and kernel width in bread wheat (Triticum aestivum L.). Journal of Applied Genetics, 51(4): 421-429.

Sahnoun, M., Kriaa, M., Besbes, S., Jardak, M., Bejar, S., and Kammoun, R. (2016). Optimization of Aspergillusoryzae S2 $\alpha$-amylase, ascorbic acid, and glucose oxidase combination for improved French and composite Ukrainian wheat dough properties and bread quality using a mixture design approach. Food Science and Biotechnology, 25(5): 1291-1298.

Sanz Penella, J. M.; Collar, C and Haros, M. (2008). Effect of wheat bran and enzyme addition on dough functional performance and phytic acid levels in bread. Journal of Cereal Science,48(3): $715-721$.

Shafisoltani, M.; Salehifar, M. and Hashemi, M. (2014). Effects of enzymatic treatment using response surface methodology on the quality of bread flour. Food Chemistry, 148: 176-183.

Steel, R.; Torrie, J. and Dickey, D. (1997). Principles and procedures of Statistics: A Biometrical Approach, $3^{\text {rd }}$ ed., McGraw-Hill, New York, NY.

Steffolani, M. E., Ribotta, P. D., Pérez, G. T., and León, A. E. (2010). Effect of glucose oxidase, transglutaminase, and pentosanase on wheat proteins: Relationship with dough properties and bread-making quality. J. Cereal Sci. 51:366-373.

Svensson, B.; Tovborg Jensen, M.; Mori, H.; BakJensen, K. S.; Bonsager, B.; Nielsen, P. K.; Kramhoft, B.; Praetorius-Ibba, M.; Nohr, J.; Juge, N.; Greffe, L.; Williamson, G and Driguez H. (2002). Fascinating facets of function and structure of amylolytic enzymes of glycoside hydrolase family 13. Biologia, 57 (11): 5-19.

Van Oort, M. (2010) Enzymes in bread making. In: Whitehurst RJ, van Oort M. (eds.) Enzymes in Food Technology, second ed. Chichester: WileyBlackwell; 2010. p. 103-143.

Whitney, K.; Jae-Bom, O and Simsek,S. (2014). Addition of Glucose Oxidase for the Improvement of Refrigerated Dough Quality. Cereal Chem. 91(6):548-553.

Yaseen, A. A. (1985). Chemical and physical studies on the characteristics of balady bread. M. Sc. Thesis, Fac.of Agric., Ain Shams Univ., Egypt

Yaseen A.A., Shouk A.A., Ramadan M.T.(2010). Corn-wheat pan bread quality as affected by hydrocolloids. J. Amer. Sci., 2010, 6, (10) 684-690 . 
تأثير إضافة بعض الإنزيمات على الخواص الريولوجية للخبز البلدى الفاخر المصنع من دقيق سخا 94

$$
\text { وليد محمد يوسف 1-- حسن على خلف 1- أثرف مهدى شرويه1 } 1
$$

1قسم الصناعات الغذائية - كلية الزراعة بمشتهر - جامعة بنها - مصر

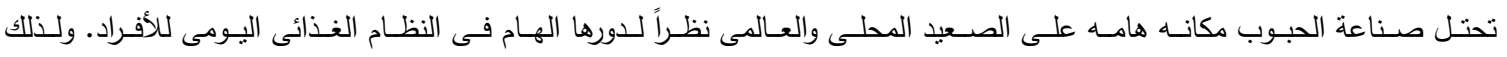

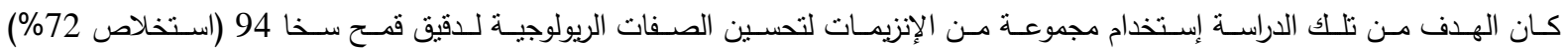

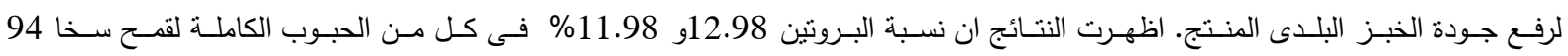

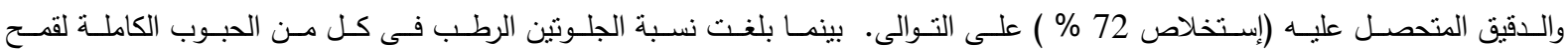

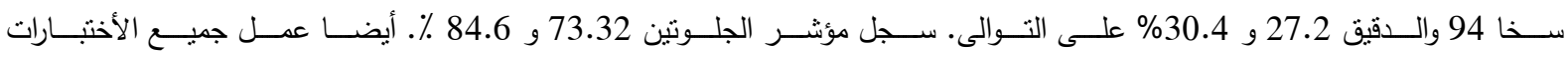

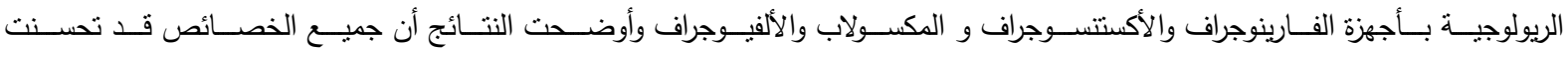

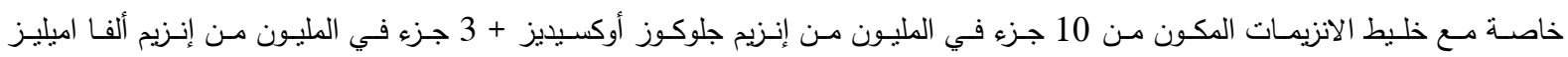

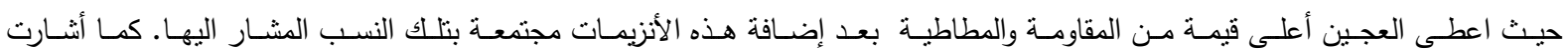

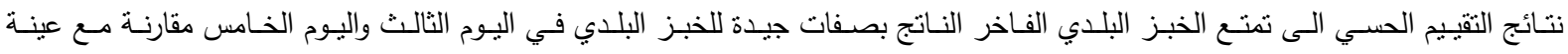
الكنترول وكذا باقى المعاملات. الكلمات الدالة: الخبز البلاى - سخا 94- إنزيمات - جلوكوز اكسيديز - ألفا اميليز 